\title{
Grouping Pig-Specific Responses to Mitogen with Similar Responder Animals may Facilitate the Interpretation of Results Obtained in an Out-Bred Animal Model
}

\author{
J. Alex Pasternak ${ }^{1,2}$, Siew Hon $\mathrm{Ng}^{1,2}$, Tobias Käser ${ }^{1}$, François Meurens ${ }^{1}$ and Heather L. Wilson ${ }^{1^{*}}$ \\ ${ }^{1}$ Vaccine and Infectious Disease Organization, home of the International Vaccine Centre (VIDO-InterVac), Canada \\ ${ }^{2}$ University of Saskatchewan, 120 Veterinary Road, Saskatoon, SK, S7N 5E3, Canada
}

"Corresponding author: Heather L. Wilson, VIDO-InterVac, University of Saskatchewan, 120 Veterinary Road, Saskatoon, SK, S7N 5E3, Canada, Tel: +1-(306) 966-1537; Fax: +1-(306) 966-7478; E-mail: heather.wilson@usask.ca

Rec date: 28 Apr 2014; Acc date: 19 Jun 2014; Pub date: 24 Jun 2014

Copyright: (c) $2014 \mathrm{~J}$. Alex Pasternak, et al. This is an open-access article distributed under the terms of the Creative Commons Attribution License, which permits unrestricted use, distribution, and reproduction in any medium, provided the original author and source are credited.

\begin{abstract}
Pig peripheral blood-derived mononuclear cells (PBMCs) and lamina propria mononuclear cells (LPMCs) stimulated with mitogens ex vivo can show significant animal-to-animal variation lead to difficulty in interpreting responses in an out-bred animal species. Mixed-cell populations were stimulated ex vivo with $2.5 \mu \mathrm{g} / \mathrm{ml}$ Con A or 2.5 $\mathrm{ng} / \mathrm{ml}$ PMA plus $250 \mathrm{ng} / \mathrm{ml}$ ionomycin (PMAi; (LPCMs only)) or media alone for 72 hours. Supernatants were then tested for cytokine production using a Bioplex assay for porcine IFNa, IFNy, IL-10, and IL-12. Unstimulated PBMCs had significant levels of IL-10 and the median value for this group decreased in the presence of Con A. Con A did, however, induce production of IFNa and IFNy, but not IL-12 in this cell population. In contrast, unstimulated and Con A-stimulated LPMCs produced negligible IL-10, IFNa, IFNy, and the majority of animals' LPMCs showed negligible IL-12 production in response to Con A. In contrast, LPMCs stimulated with PMAi produced IFNy suggesting cytokine production is mitogen-specific response. When we tracked animal-specific responses, we observed that discrete subsets of animal's PBMCs responded to Con A with significantly increased or decreased IL-10 production relative to unstimulated cells. Further, in the LPMCs, some cells produced no IL-12 in response to Con A but showed augmented production in response to PMAi, while others showed production of IL-12 in response to Con A but no response to PMAi. Flow cytometric analysis showed that the PBMCs were a mixture of CD3+ $T$ cells $>C D 21+B$ cells $>$ CD172+ myeloid cells whereas the LPMCs consisted of mainly Cytotoxic T cells and Natural Killer cells. The percentage of CD8 $\alpha+C D 4+$ antigen-experienced $T$ cells was greater in the LPMCs relative to the PBMCs. As expected in an out-bred species, animal-specific differences in cytokine production in response to stimulants exist and may confound interpretation of results unless tracked individually.
\end{abstract}

\section{Introduction}

Because of the increased demand for swine and their byproducts, pig farming has become a major agricultural industry with barns processing large numbers of pigs. Thus, the pig industry is vulnerable to outbreaks of disease which can have enormous economic impact worldwide [1]. The industry has been proactive in its search for effective prophylactic strategies, therapeutic treatments and vaccines to control and/or prevent diseases [2-5]. Studies designed to understand the porcine immune system and its underlying functional responses to drugs, mitogens, and immunomodulators are critical to the design of effective treatments and/or vaccines to protect against disease.

The Gut-Associated Lymphoid Tissue (GALT) is comprised of organized inductive sites (Peyer's Patches (PP), isolated lymphoid follicles, and draining lymph nodes) and effector sites (non-organized lymphoid tissue diffusely distributed throughout the Lamina Propria (LP) [6]. In the theory of the common mucosal immune system, activated $\mathrm{T}$ and $\mathrm{B}$ cells get sensitized at specific mucosal sites such as inductive sites in the GALT. They leave the site of initial antigen encounter via the lymphatics, transit through the circulatory system, and migrate to mucosal effector sites such as the LP, where B cells continue to expand and differentiate [7-8]. As well as homing back to their site of origin, lymphocytes also seed other mucosa sites which may be tremendously valuable in protecting the host against further infections [7,9-11]. In the gut, the LP lies beneath the basement membrane and is comprised of most of the components of the immune system such as B cells, plasma cells, and macrophages, dendritic cells (DCs) and T cells [12-13]. Because leukocytes from the LP originally circulated through the blood and because PBMCs are also composed of large numbers of $\mathrm{B}$ cells, plasma cells, $\mathrm{T}$ cells and myeloid cells, we will compare the mitogenic responses of the LP cells to the mitogenic response from Peripheral Blood Mononuclear Cells (PBMC) population to discern if the responses are conserved across tissues or differ widely in these distinct mixed-cell populations [12].

The magnitude of the proliferative response of PBMCs to the T cell mitogen concanavalin A (Con A) has long been used as an indirect measure of the responsiveness of the immune system to antigenic stimulation [13]. Phorbol 12-myristate 13-acetate (PMA) activates Protein Kinase $\mathrm{C}$ (PKC) while Ionomycin is a calcium ionophore and together (PMAi) they bypass the T-cell receptor (TCR) complex, trigger $\mathrm{T}$-cell activation and signal through several intracellular signaling pathways [14]. While PMAi and Con A activate T cells it is important to remember that these mitogens can also act on monocytes, DCs and other members of a mixed-cell population so cytokine production cannot be automatically attributed to the $\mathrm{T}$ cell population [13,15-18]. Cytokine production can be influenced by the site of cell isolation, the cellular composition and the mitogen used. 
Citation: Pasternak JA, Ng S, Kaser T, Meurens F, Wilson HL (2014) Grouping Pig-Specific Responses to Mitogen with Similar Responder Animals may Facilitate the Interpretation of Results Obtained in an Out-Bred Animal Model . J Vaccines Vaccin 5: 242. doi: $10.4172 / 2157-7560.1000242$

Page 2 of 9

We investigated production of a several cytokines reflecting the immune response on viral infections (Interferon (IFN)a) as well as a T-helper type (Th) 1 (IL-12, IFN $\gamma$ ) or Th2-type (IL-10) immune response in pig PBMCs and LP mononuclear cells (LPMCs). Myeloid cells may also be a source of IL-10 production in pigs [19-20]. Type I IFNa, is critical to promote immunity against viruses and can be triggered in many cell types, especially plasmacytoid dendritic cells [21-22]. IFNa can induce T-cell activation or long-term survival, production of IFN $\gamma$ and Th1 differentiation [23]. IFNa can promote DC differentiation, maturation and immunostimulatory functions and, through production of both type I interferons and IL-6, IFNa can induce human $\mathrm{B}$ cells to differentiate into plasma cells and produce immunoglobulin [24-25].

IL-12 is a multi-functional cytokine that bridges the early nonspecific innate resistance and the subsequent antigen-specific adaptive immunity via a Th1 response [26]. IL-12 is naturally produced by dendritic cells [27-29] and macrophages [30] and can stimulate T-cell growth and differentiation of naïve $\mathrm{T}$ cells into Th1 cells [31].

CD4+ Th1 cells are required for response against intracellular infections; they produce IFN $\gamma$ and promote both macrophage and Bcell activation [32-34]. Th2 cells synthesize IL-4, IL-10 and IL-13 cytokines, they are responsible for protection against extracellular pathogens and they provide optimal help for antibody production and promote both mast cell growth and eosinophil differentiation [35-37]. Th1 and Th2 development is mutually exclusive as expression of either IFN $\gamma$ or IL-4 antagonizes expression of the other [38-39]. Th17 cells also help protect against extracellular pathogens, they are potent inducers of tissue inflammation and have been associated with the pathogenesis autoimmune diseases [40]. These cells have recently been observed in pigs [41].

Studies in two-month old pigs showed that the porcine immune system is sufficiently mature to be able to selectively control the response of cytokine producing cells to mitogenic stimulation [42]. In this study, cytokine production from PBMCs and LPMCs was determined in 24 and 15 pigs, respectively. We measured baseline and stimulated cytokine production in the presence of the Con A or PMAi. We investigated the response to polyclonal $\mathrm{T}$-cell activators rather than an antigen-specific immune response because we aim to investigate the capacity of pig leukocytes to produce cytokines without interference from other components of the immune system. The aim of the present study was to demonstrate how mixed-cell populations taken from discrete regions of the body produce distinct cytokine profiles in response to Con A or PMAi and that animal-specific responses can differ widely. We then tracked the animal-specific responses to Con A and PMAi to discern whether grouping similar responder animals facilitates the interpretation of results obtained in out-bred animal model.

\section{Materials and methods}

\section{Animal use and ethics}

This work was approved by the University of Saskatchewan's Animal Research Ethics Board, and adhered to the Canadian Council on Animal Care guidelines for humane animal use. Seven-week old Landrace cross piglets were obtained from several litters from the Prairie Swine Centre, Inc. (PSCI), Saskatoon, SK, Canada.
PBMC isolation and stimulation: PBMCs were isolated from 49 day old pigs by Ficoll gradient centrifugation following the protocol described by Buchanan et al. [43]. Stimulation of PBMCs were performed in 96-well, round-bottom plates (Nunc, Naperville, Ill., USA) using AIM V medium supplemented with $10 \%$ fetal bovine serum (FBS) (Invitrogen, Burlington, ON, CA), $2 \mathrm{mM} \mathrm{L}$-glutamine, $50 \mu \mathrm{M} 2$-mercaptoethanol and $10 \mu \mathrm{g} / \mathrm{ml}$ polymyxin B sulfate (SigmaAldrich, Oakville, ON, Canada; for all) as described before [12]. Cells were ex vivo stimulated with $2.5 \mu \mathrm{g} / \mathrm{ml}$ Con A (Sigma-Aldrich), 2.5 ng/ml, PMA (Sigma-Aldrich) plus $250 \mathrm{ng} / \mathrm{ml}$ ionomycin (SigmaAldrich) or media alone for 72 hours. For each treatment, $5 \times 105$ cells were cultured in triplicate wells in $200 \mu$ l total volume. Culture supernatants were harvested and stored at $-20{ }^{\circ} \mathrm{C}$ until assayed for IL-10, IL-12, IFNa and IFN $\gamma$.

\section{LPMC isolation and stimulation}

Three inch segments of Peyer's Patch-free jejunum were inverted and washed in Calcium-free Krebs-Henseleit-bicarbonate (KHB; 119 $\mathrm{mM} \mathrm{NaCl}, 4.8 \mathrm{mM} \mathrm{KCl}, 1.2 \mathrm{mM} \mathrm{MgSO}_{4}, 1.2 \mathrm{mM} \mathrm{KH}_{2} \mathrm{PO}_{4}, 25 \mathrm{mM}$ $\left.\mathrm{NaHCO}_{3}, \mathrm{pH} 7.4\right)+2.5 \mathrm{mM} \mathrm{CaCl}_{2}$ (Sigma-Aldrich for all) and dabbed onto wet paper towel to remove intestinal contents and mucous. The intestine was sealed via ligature then inflated by injection of $\mathrm{KHB}+$ $\mathrm{CaCl}_{2}$ into the lumen and the other end was also sealed via ligature. The inverted segments were incubated in KHB buffer+ $5 \mathrm{mM}$ EDTA (Sigma-Aldrich) for 20 minutes at $37^{\circ} \mathrm{C}$ and $150 \mathrm{RPM}$ to slough off the majority of epithelial cells and intra-epithelial lymphocytes. Segments were rinsed in $\mathrm{KHB}+\mathrm{EDTA}$ buffer then transferred to a clean flask containing $100 \mathrm{ml}$ RPMI Complete (RPMI 1640 (Invitrogen, Gibco \#21870-076) plus 10\% FBS (Invitrogen), $50 \mu \mathrm{g} / \mathrm{ml}$ \-Mercaptoethanol (Sigma-Aldrich), 1:100 Antibiotic/antimycotic (Invitrogen, Gibco \#15240-062); 1:100 HEPES (Invitrogen, Gibco \#15630-080), 1:100 MEM Non-Essential Amino Acids (Invitrogen, Gibco \#11140-050) and $2 \mathrm{mM}$ L-Glutamine (Invitrogen, Gibco \#25030-081)) with 100 $\mathrm{U} / \mathrm{ml}$ Collagenase (C9263, Sigma-Aldrich) for 45 minutes at $37^{\circ} \mathrm{C}$ and 150 RPM to remove LPMCs. The intestinal segment was washed with RPMI Complete to remove cells of interest, then tissue was discarded. The cells were pelleted out of solution at $350 \mathrm{~g}$ for $5 \mathrm{~min}$ then resuspended in $10 \mathrm{ml}$ RPMI Complete. Cells were filtered through a 40 $\mu \mathrm{m}$ Nylon Cell Strainer (BD Falcon, Durham, NC, USA). Cells were counted via Trypan Blue Exclusion assay using a hemocytometer and resuspended at a final concentration of $0.5 \times 107$ live cells $/ \mathrm{ml}$. Cell stimulations was performed as indicated above.

\section{Flow cytometric analysis}

PBMCs or LPMCs $(1 \times 106)$ were stained for $10 \mathrm{~min}$ in a $30 \mu \mathrm{l}$ volume of PBS with 2\% FBS (Invitrogen) using the primary antibodies at concentrations previously titrated in our lab as follows: anti-CD3 (Southern Biotech (4510-01; $1.6 \mu \mathrm{g} / \mathrm{ml}$; Mouse IgG1; Birmingham, AL 35209, USA)), anti-CD4 (VMRD (74-12-4; $33.3 \mu \mathrm{g} / \mathrm{ml}$; Mouse IgG2b; Pullman, WA 99163, USA)), anti-CD8a (AbD Serotec (MCA1223; 3.3 $\mu \mathrm{g} / \mathrm{ml}$; Mouse IgG2a; Raleigh, NC, USA)), anti-CD21 (BD Biosciences, San Jose, CA, USA) (555421; $0.83 \mu \mathrm{g} / \mathrm{ml}$; Mouse IgG1; Mississauga, ON, L5N 0B3, CA)) and anti-CD172 (VMRD (74-22-15A; $0.53 \mu \mathrm{g} / \mathrm{ml}$; Mouse IgG2b)). Cells were washed twice with $200 \mu \mathrm{l}$ of PBS $+2 \%$ FBS (Invitrogen) then pelleted by gently centrifugation for $3 \mathrm{~min}$. Cells were then stained with fluorescent secondary antibodies against goat anti mouse IgG1 (APC, Southern Biotech 1070-11S), IgG2a (PE, Southern Biotech 1082-09) and IgG2b (FITC, Southern Biotech $1092-02)$ at $0.8 \mu \mathrm{g} / \mathrm{ml}$. Cells were washed twice as indicated above then 
Citation: Pasternak JA, Ng S, Kaser T, Meurens F, Wilson HL (2014) Grouping Pig-Specific Responses to Mitogen with Similar Responder Animals may Facilitate the Interpretation of Results Obtained in an Out-Bred Animal Model . J Vaccines Vaccin 5: 242. doi: $10.4172 / 2157-7560.1000242$

Page 3 of 9

suspended in $200 \mu \mathrm{PBS}+2 \%$ FBS (Invitrogen) and analysed on a FACSCalibur Flow Cytometer using CellQuest Pro (BD Biosciences). Final gating and analysis was conducted using FlowJo software version 7.6 (Tree Star, Ashland, OR, USA) with results presented as a percentage of gated leukocytes except the CD8a+CD4+ T cells which were presented as a percentage of all CD4+ T cells.

Bioplex cytokine assays: Bioplex bead coupling was performed as per the manufacturer's instructions. The reagents were as follows: Coating antibody: monoclonal anti-porcine IFNa (Gene Tex GTX11408), Detection antibody: monoclonal anti-porcine IFNa biotin (PBL 27105-1), Standard: recombinant porcine IFNa (Genetech), Bead: region 45 (BioRad MC10045-01). Coating antibody: monoclonal anti-porcine IFN $\gamma$ (Fisher ENMP700), Detection antibody: monoclonal anti-porcine IFN $\gamma$ (Fisher ENPP700; biotinylated inhouse), Standard: recombinant porcine IFN $\gamma$ (clone 2-2-1; biotinylated in-house), Bead: region 43 (BioRad MC10043-01). Coating antibody: monoclonal anti-porcine IL-10 (Invitrogen ASC0104), Detection antibody: monoclonal anti-porcine IL-10 biotin (Invitrogen ASC9109), Standard: recombinant porcine IL-10 (Invitrogen PSC0104), Bead: region 28 (BioRad MC10028-01). Coating antibody: monoclonal anti-porcine IL-12 (Kingfisher MA0413S-C), Detection antibody: monoclonal anti-porcine IL-12 biotin (R\&D BAM9122), Standard: recombinant porcine IL-12 (R\&D 912-PL-026), Bead: region 36 (BioRad MC10036-01). The multiplex assay was carried out in a 96 well Grener Bio-One Fluotrac $20096 \mathrm{~F}$ black (VWR, \#82050-754) which allows washing and retention of the Luminex beads. The porcine IFNa, porcine IFN $\gamma$, porcine IL-10 and porcine IL-12 protein standards were added to the wells at $50 \mu \mathrm{l}$ per well at a final concentration of $200 \mathrm{pg} / \mathrm{ml}, 2000 \mathrm{pg} / \mathrm{ml}, 5000 \mathrm{pg} / \mathrm{ml}$ and $5000 \mathrm{pg} / \mathrm{ml}$, respectively. The PBMC supernatants were prediluted 1:3 and added to the wells at $50 \mu \mathrm{l}$ per well. The 4 beadsets conjugated with the IFNa, IFN $\gamma$, IL-10 and IL-12 antigens were vortexed for 30 seconds followed by sonication for another 30 seconds to ensure total bead dispersal. The bead density was adjusted to 1200 beads per $\mu \mathrm{l}$ in PBS-BN (1x PBS + 1\% BSA (Sigma-Aldrich) + $0.05 \%$ sodium azide (Sigma-Aldrich), $\mathrm{pH}$ 7.4) and $1 \mu \mathrm{l}$ of each beadset was added to $49 \mu \mathrm{l}$ of the PBSA $+1 \%$ New Zealand Pig Serum (Sigma-Aldrich P3484) + $0.05 \%$ sodium azide (Sigma-Aldrich) which was then added to each well. The plate was sealed with plate sealer (Thermo Fisher Scientific, $\# 12565491$ ) and covered with foil lid. The plate was agitated at 800 rpm for 1 hour at room temperature. After 1 hour incubation with serum, the plate was washed using the Bio-Plex ProII Wash Station (Bio-Rad; soak $60 \mathrm{~s}$, wash with $300 \mu \mathrm{l}$ PBST). A $50 \mu \mathrm{l}$ of biotin cocktail consisting of biotinylated porcine IFNa (PBL 27105-1; 1/5000; biotinylated in-house), biotinylated porcine IFN $\gamma$ (Fisher ENPP700; 1/300; biotinylated in-house), biotinylated porcine IL-10 (Invitrogen ASC9109; $0.5 \mu \mathrm{g} / \mathrm{ml}$ ) and biotinylated porcine IL-12 (R\&D BAM9122; $0.5 \mu \mathrm{g} / \mathrm{ml}$ ) was added to each well. The plate was again sealed, covered and agitated at $800 \mathrm{rpm}$ for 30 minutes at room temperature then washed again as indicated above. A $50 \mu \mathrm{l}$ of Streptavidin RPE (Cedarlane PJRS20; diluted to $5 \mu \mathrm{g} / \mathrm{ml}$ ) was added to each well. The plate was again sealed, covered and agitated at $800 \mathrm{rpm}$ for 30 minutes at room temperature and washed as indicated above. A $100 \mu \mathrm{l}$ of $1 \mathrm{x}$ Tris-EDTA was added to each well and then the plate was vortexed for 5 minutes before reading on the Luminex100 $\mathrm{xMAP}^{\mathrm{si}}$ instrument following the manufacturer's instructions and as described in (Anderson et al., 2011). The instrument was set up to read beadsets in regions 45, 43, 28 and 36 for IFNa, IFN $\gamma$, IL-10 and IL-12, respectively. A minimum of 60 events per beadset were read and the median value obtained for each reaction event per beadset. For all samples the multiplex assay MFI data was corrected for subtracting the background levels.

\section{Statistical analysis}

The outcome data from this study were not normally distributed and therefore, differences among experimental groups were tested using Kruskal-Wallis analysis and medians were compared using Dunn's test. Differences were considered significant if $\mathrm{p}<0.05$. All statistical analyses and graphing were formed using GraphPad Prism 5 software (GraphPad Software, San Diego, CA).

\section{Results and Discussion}

\section{Influence of Con A on cytokine production from PBMCs}

Con A is a T-cell mitogenic lectin that has been used extensively to evaluate lymphocyte activation responses $[42,44]$. As well as their role in $\mathrm{T}$ cell activation, Con $\mathrm{A}$ also can bind to and activate monocytes. In fact some studies show that monocytes are required for $\mathrm{T}$ cells to proliferate in response to Con A [45-46] while previously work in our lab showed that sorted porcine $\mathrm{T}$ cells proliferate well after Con $\mathrm{A}$ stimulation even in the absence of myeloid cells (unpublished observations from one of the authors). When we investigated IL-10 and IL-12 production from PBMCs isolated from pigs, we observed that a number of the unstimulated cells had high baseline IL-10 production and that Con A stimulation did not significantly increase the median IL-10 value (Figure 1a; left side). In contrast, unstimulated PBMCs did not show a baseline IL-12 production nor did they show augmented IL-12 production in response to Con A (Figure 1b; left side). Käser et al. (2008) showed that purified blood-derived pig CD4+ T cells produced IL-10 in response to Con A and they further specified that the IL-10 producing population was predominately CD4+CD25dim T cells, not T regulatory cells (CD4+CD25high) [47]. Our data also shows partial agreement with Andersson et al. (2007) who showed that pig PBMCs showed induced IL-10 gene expression but no change in IL-12 gene expression in response to Con A [48]. Further, our data showed that in pig PBMCs, Con A significantly induced production of IFNa ( $\mathrm{p}<0.0001$; Figure $1 \mathrm{c}$; left side) and IFN $\gamma$ $(\mathrm{p}<0.0001$; Figure 1d; left side) relative to unstimulated cells. These data show agreement with Chuang et al. 2009 who showed, using ELISPOT analysis, that human PBMCs produced low levels of IFN $\gamma$ secreting cells in response to Con A [49]. Donaldson et al, 2005 used a custom-designed innate immunity microarray to investigate Con A stimulation of PBMC in cattle over a 24 hour period. They saw induction of the gene coding for IFN $\gamma$ in response to Con A which shows agreement with our study (although we evaluated changes in protein expression) [50]. However, our data also contrasted with results from numerous other studies. For instance, Wilkinson et al looked at transcriptomic profile of porcine PBMCs to Con A stimulation for up to 68 hours [51]. They comment that one of the genes most up-regulated in response to Con A was TNFRSF9 (also known as 4-1BB) which encodes a receptor that signals to maintain $\mathrm{T}$ cell proliferation and promote the release of Th1 cytokines [51]. Despite this, their study did not show that pig PBMCs responded to Con A with induced expression of IFN $\gamma$, the classical Th1 cytokine. Also in contrast to our data, their transcriptomic analysis failed to show induced IL-10, IL-12 or IFNa expression in response to Con A. Raskova et al, 2005 determined that Con A alone had no stimulatory effect on IFN $\gamma$ - secreting cells in pig PBMCs relative to unstimulated cells [42]. Together these responses show that PBMC production of 
Citation: Pasternak JA, Ng S, Kaser T, Meurens F, Wilson HL (2014) Grouping Pig-Specific Responses to Mitogen with Similar Responder Animals may Facilitate the Interpretation of Results Obtained in an Out-Bred Animal Model . J Vaccines Vaccin 5: 242. doi: $10.4172 / 2157-7560.1000242$

Page 4 of 9

cytokines in response to Con A may not be consistent across all species and/or may be highly sensitive to timing of analysis, concentration of Con A, or method of analysis. Differences in response across the literature may be due to inconsistent mitogen concentrations and/or ages of animals under investigation [52].
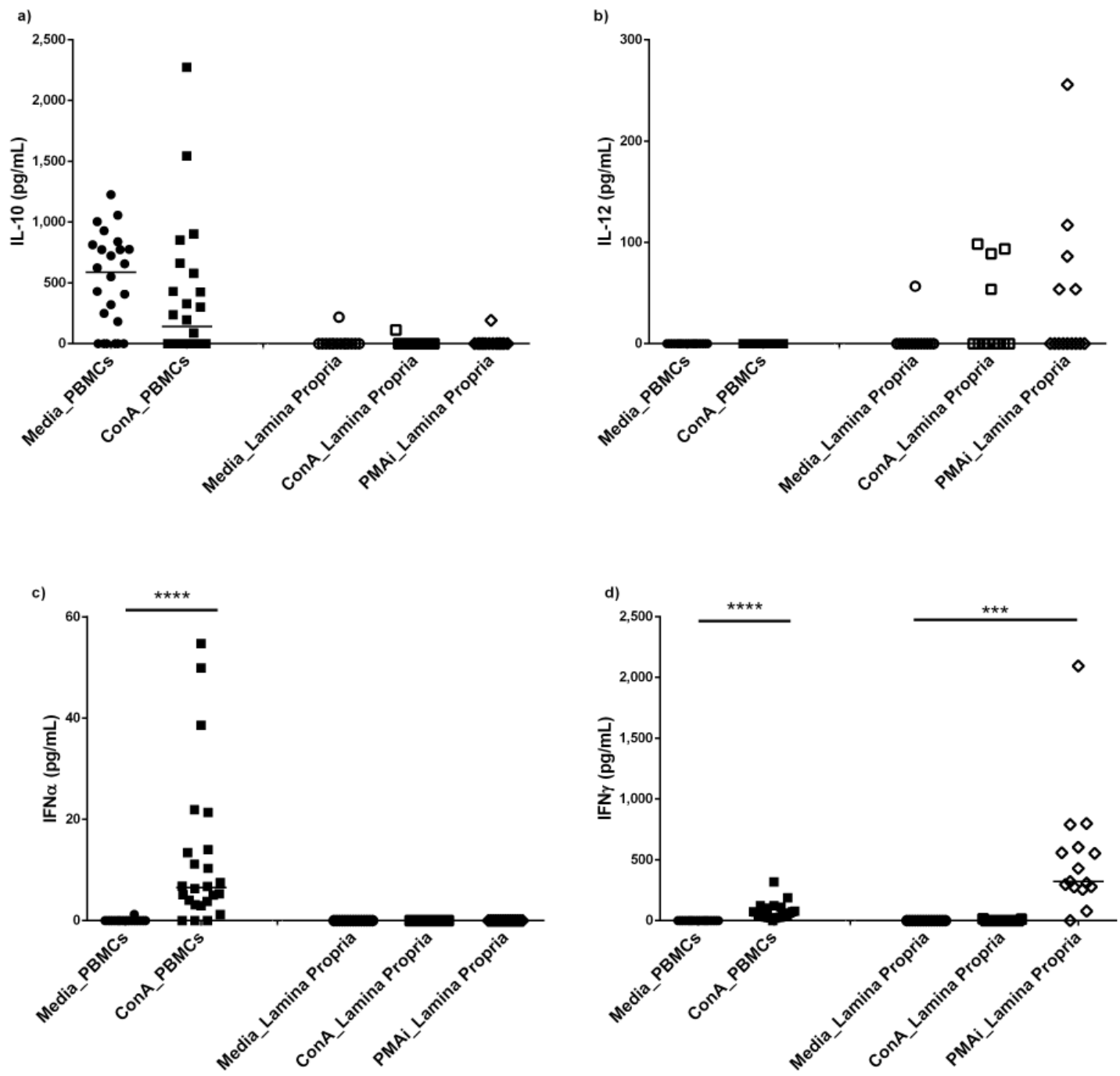

Figure 1: Porcine PBMCs and LPMCs show distinct cytokine production profiles in response to Con A or PMAi. IL-10 (a), IL-12 (b), IFNa (c) and $\operatorname{IFN} \gamma(\mathrm{d})$ cytokine concentrations were obtained at once using a BioPlex assay in seven week old pigs. Data shown are presented as the mean of duplicate concentrations for individual biological replicates and the horizontal line represents the median value for the group. ${ }^{* * *}$ $\mathrm{p}<0.001 ;{ }^{* * * *} \mathrm{p}<0.0001$

\section{Influence of Con A on cytokine production from LPMCs}

The level of cytokine production in response to Con A within the LPMCs was quite different from what was observed in the PBMC population. For instance, unstimulated and Con A-stimulated LPM cells failed to produce IL-10 and LPMCs failed to induce IFNa and IFN $\gamma$ production in response to Con A (Figure 1a, 1c, 1d; right side). These data suggest that CD8 $\alpha+$ LP T cells are poor producers of these cytokines in response to Con A. While no PBMCs showed induced expression of IL-12 in response to Con A, four of the fifteen pigs showed Con A-induced IL-12 expression (Figure 1b; right side). Because IL-12 is produced by dendritic cells and monocyte/ macrophages and it promotes IFN $\gamma$ production in blood-derived NK cells and T cells [53-54], one may expect that if IL-12 is produced within the LPMCs (Figure 1b), that there would likely be a rise in the production of IFN $\gamma$, which was not observed (Figure 1d). However, Cella et al. 2009 also showed that while IL-12 induced IFN $\gamma$ in blood NK cells, it failed to induce IFN $\gamma$ in intestinal NK cells suggesting that cells obtained from different locations in the body do not respond 
uniformly to mitogens [55]. Further, our data shows agreement with Chuang et al. who showed that ELISPOT analysis of human gut LPMCs showed a negligible increase in the number of IFN $\gamma$-secreting cells in response to Con A [49]. In contrast, others show that intestinal LPMCs from normal nonhuman primates responded to Con A with increased mRNA coding for IFN $\gamma$ [56]. Whether the corresponding proteins levels also changed was not evaluated. Collectively, our data shows that in pigs, Con A-induced cytokine productions from distinct mixed-cell populations are not conserved.

\section{Influence of PMAi on cytokine production from LPMC}

Because Con A failed to induce production of IFNa, IFN $\gamma$ or IL-10 in LPMCs, we next wanted to evaluate whether these cells responded to another activator. PMA activates Protein Kinase $\mathrm{C}$ while Ionomycin is a calcium ionophore, which will lead to activation of several intracellular signaling pathways [14,57-58]. To ensure that PMA/ Ionomycin (PMAi) concentrations were not toxic to the pig LPMCs, we performed a dose titration and determined that $2.5 \mathrm{ng} / \mathrm{ml}$ PMA plus $250 \mathrm{ng} / \mathrm{ml}$ ionomycin concentration induced an average of $15 \%$ proliferation after 3 days (data not shown). Our BioPlex data showed that LPMCs responded to PMAi with negligible IL-10 and IFNa and only five animals responded with IL-12 production (Figure 1a, 1c, 1b; right side). However, LPMCs from all but one pig responded to PMAi with relatively high production of IFN $\gamma$ (Figure 1d; right side) which was significantly higher than the control population $(\mathrm{p}<0.001)$. The subset population in the porcine LPMCs responsible for IFN $\gamma$ production showed preferential responsiveness to PMAi but not Con A further indicating that the site from which cells are isolated (with what is likely a very distinct cellular composition) and the mitogen chosen for activation can have profound effect on leukocyte-derived cytokine production.

\section{Distinct animal-specific responders:}

By tracking animal specific responses to stimulation (or baseline cytokine expression in response to media alone), we see patterns of responses emerging that are not evident when simply the median responses are evaluated. Livestock pigs are out-bred animals, means that within a group there are commonly disparate responses to treatment. If we track the animal-specific changes in IL-10 cytokine production within the PBMCs, we observe that cells from some animals respond to Con A with increased IL-10 production whereas other respond with decreased IL-10 production relative to the unstimulated cells (Figure 2a; left side). When we break the group into responders and non-responders (right side of the graph), we observe that PBMCs from a number of pigs that showed high baseline IL-10 production (Media (Decr)) showed significantly reduced $(\mathrm{p}<0.0001)$ IL-10 production in response to Con A (Con A (Decr)), while at the same time PBMCs from other pigs that showed high baseline IL-10 production (Media (Incr)) showed significantly increased $(\mathrm{p}<0.05)$ IL-10 production in response to Con A (Con A (Incr)) (Figure 2a). Further, PBMCs from some animals failed to show IL-10 production regardless of whether they were simulated with Con A or not (nonresponders). Our data does not specify whether the IL-10 producing cells are of myeloid or lymphoid origin.

Similarly, when we evaluated the production of IL-12 in LPMCs, we observe that the majority of animals had negligible IL-12 production but that some LPMCs responded to Con A with increased IL-12 production (Figure $2 \mathrm{~b}$; responders: left side) but others did not (Figure 2b; non-responders: right side). From the animals that produced IL-12 in response to Con $\mathrm{A}$, with the exception of one animal, they responded with negligible IL-12 production in response to PMAi (Figure 2b). As well, cells from animals which failed to produce IL-12 in response to Con A stimulation produced high levels of IL-12 in response to PMAi. And again, some animals' cells did not produce IL-12 in response to either Con A or PMAi (non-responders). Although the differences in IL-12 production in response to Con A or PMAi do not meet the criteria of being statistically different from each other, discrete patterns of expression were evident when were investigated individual animal responses to mitogen.

If $\mathrm{T}$ cells are responsible for IL-10 production, we anticipate that they are Th2 cells and would necessarily produce negligible IFN $\gamma$ [59]. We investigated whether the PBMCs from the animals that had high baseline and Con A-induced expression of IL-10 had reduced expression of IFN $\gamma$. As indicated in the right-side of Figure 2a, there is a group of animals that show high levels of IL-10 in the absence of Con A (Figure 2a, Media (Incr) which produced significantly increased expression of IL-10 in the presence of Con A (Figure 2a, ConA (Incr).

The unstimulated cells from this group of animals (same as Figure 2, filled circles) will be referred to as 'IL-10 (Media (Incr)' in Figure 3 and the corresponding Con A-stimulated cells will be called 'IL-10 (ConA (Incr)' in Figure 3. Similarly, there is a group of animals that showed high levels of IL-10 in the absence of Con A (Figure 2a, Media (Decr) and lower IL-10 production in the presence of ConA (Figure 2a, ConA (Decr). In Figure 3, the unstimulated cells from this group of animals will be referred to as 'IL-10 (Media (Decr)' and the corresponding Con A-stimulated cells will be called 'IL-10 (ConA (Decr))'. We charted the IL-10 production on the left $y$-axis and the corresponding IFN $\gamma$ production was charted on the right $y$-axis (Figure 3). For both the 'IL-10 (Media (Incr))' and 'IL-10 (Media (Decr)) groups, we observed high IL-10 with negligible baseline IFN $\gamma$ production suggesting a low IFN $\gamma$ to IL-10 ratio (i.e. a Th2 type immune response). The Con A-stimulated cells in the 'IL-10 (ConA(Incr) group all produced relatively high concentrations of both IL-10 and IFN $\gamma$. Because Th2 cells produce IL-10 and Th1 cells produce IFN $\gamma$, these results indicate that likely two populations of cells are responsible for production of these cytokines. A single trend was not observed in the group of Con A-stimulated cells referred to as 'IL-10 (ConA (Decr)). From this group, 9 /15 animals had negligible IL-10 production but produced low to moderate levels of IFN $\gamma$. The remaining six animals from this group produced relatively high concentrations of IL-10 and IFN $\gamma$ in response to Con A. Together these data again may indicate two cell types are responsible for producing the cytokines. Differences in mixed-cell population responses to a stimulant are not unexpected when we consider that pigs are an out-bred species with potentially diverse inherent biological variation. Others have shown that the biological variability amongst an out-bred population such as humans and cattle are profound and made it very difficult to generate statistically significant results [60-62]. It has been suggested that variation in Con A responsiveness of human peripheral lymphocytes may be partly related to differences in purification which give rise to cell preparations containing varying amounts of monocytes [63]. From these results, we suspect that there are likely at least two subsets of cells that are responsible for the cytokine production in this mixed cell population but this would have likely gone unobserved if the animalspecific responses to mitogen were not tracked and grouped together. 
Citation: Pasternak JA, Ng S, Kaser T, Meurens F, Wilson HL (2014) Grouping Pig-Specific Responses to Mitogen with Similar Responder Animals may Facilitate the Interpretation of Results Obtained in an Out-Bred Animal Model . J Vaccines Vaccin 5: 242. doi: $10.4172 / 2157-7560.1000242$

Page 6 of 9

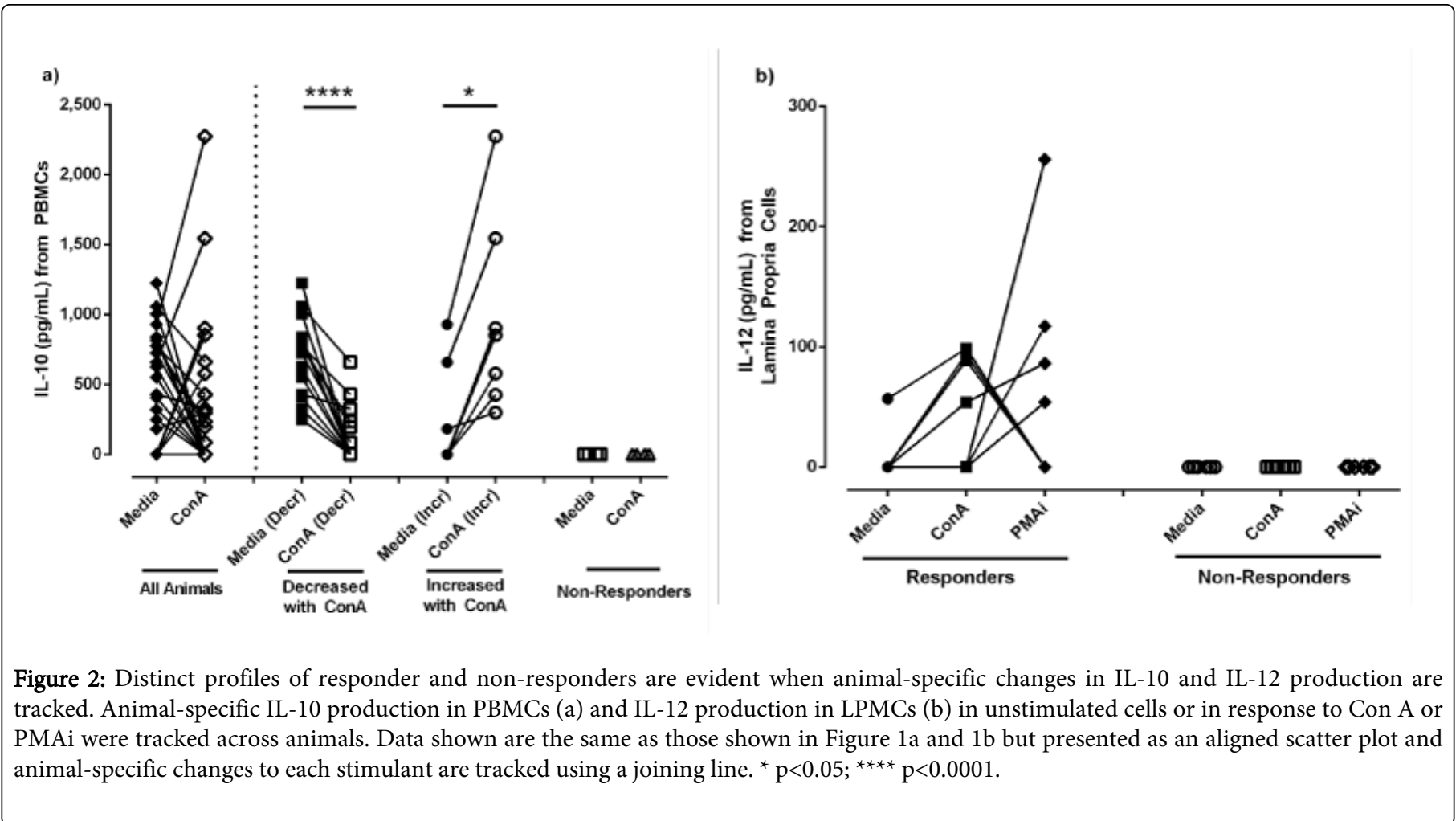

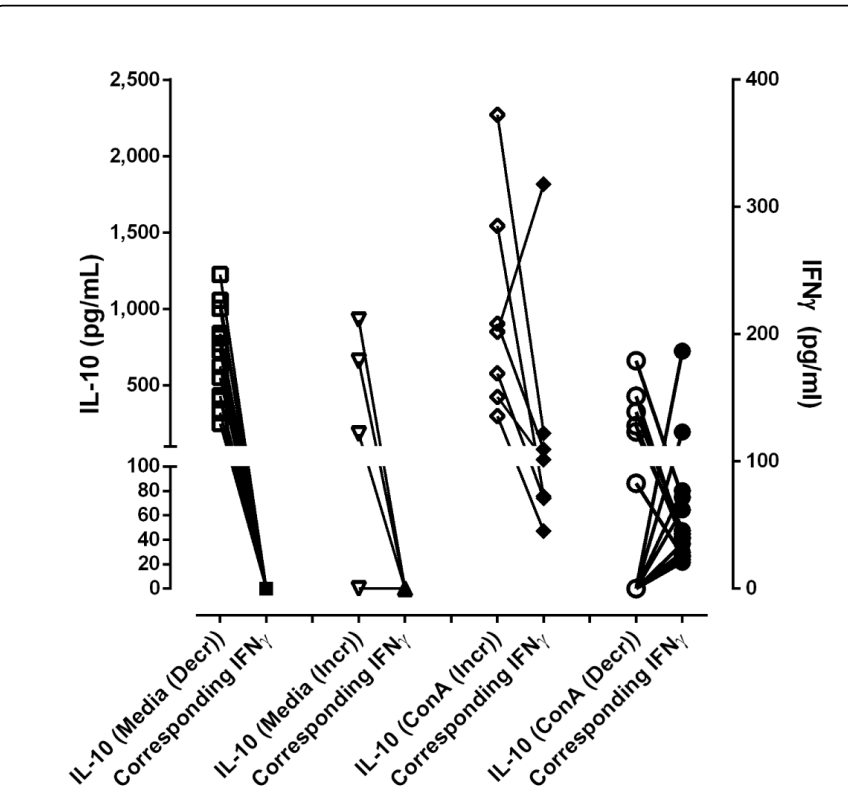

Figure 3: Distinct profiles of responders and non-responders are evident when the ratio of IL-10:IFN $\gamma$ in PBMCs are tracked across animals. The left Y-axis represents IL-10 concentrations and the right $\mathrm{Y}$-axis represents IFN $\gamma$ concentrations. Animal-specific ConA-induced IL-10 and IFN $\gamma$ production were tracked. Data shown are the same as those shown in Figure 1a and 1d but presented as an aligned scatter plot and animal-specific changes to each cytokine production are tracked using a joining line.

\section{Cellular composition of PBMC and LPMCs:}

To gain a better understanding of cells responsible for the cytokine production above, we investigated the cellular composition of the PBMC and LPMC populations. Because PBMCs are acquired from the circulatory system and the LPMCs are derived from a tissue, it is not surprising that our data shows that the PBMCs are largely comprised of leukocytes (Figure 4a) but that the leukocytes represent a minority population in the LPMCs (Figure 4h), with the majority of LPMCs likely being epithelial or stromal cells. Flow cytometric analysis from PBMCs and LPMCs from four different pigs indicates that CD172+ myeloid cells represent a moderate percentage of the PBMCs (Figure $4 \mathrm{~b} ; 7.2 \% \pm 1.5$ ) but are virtually absent in the LPMCs (Figure $4 \mathrm{i} ; 0.7 \%$ \pm 0.5). Similarly, the B cells $(\mathrm{CD} 21+)$ cells represent a major population within the PBMCs (Figure $4 \mathrm{e} ; 27.8 \% \pm 2.3$ ) but are virtually absent from the LPMC population (Figure 41; $0.3 \% \pm 0.3$ ). Within both the PBMC and the LPMC populations, the CD3+ lymphocytes comprise a very large portion of the total leukocyte population of cells (Figure $4 \mathrm{~d} ; 56.4 \% \pm 6.4$, Figure $4 \mathrm{k} ; 74.0 \pm 5.3$, respectively). The percentage of $\mathrm{CD} 3+\mathrm{T}$-cell subsets in the PBMCs was as follows: cytotoxic T cells (CTLs; Figure $4 \mathrm{f} ; 9.1 \% \pm 2.7$ ) and CD4+ T cells (Figure 4f; $27.8 \% \pm 4.4$ ). The percentage of CD3+ T-cell subsets in the LPMCs (Figure 4k) were as follows: CTLs (Figure $4 \mathrm{~m} ; 54.1 \% \pm 6.6$ ) which is approximately 6 -fold higher than the corresponding PBMC population and CD4+ T cells (Figure $4 \mathrm{~m} ; 2.7 \% \pm 1.0$ ) which is 10 -fold lower than the corresponding PBMC population. In figure $4 \mathrm{~g}$ and $4 \mathrm{n}$, histograms show that there is a higher relative increase in the number of CD8 $\alpha+C D 4+T$ cells (which represent antigen-experienced $\mathrm{T}$ cells) in the LPMC population versus the PBMC population. Finally, the percentage of NK cells was $4.3 \% \pm 3.1$ in the PBMCs (Figure 4c) and $13.8 \% \pm 5.8$ in the LPMC population (Figure $4 \mathrm{j}$ ). The total percentage leukocyte for each subtype for each individual animal is shown in Figure 4o. There was significantly higher total leucokyes, B cells, 
Citation: Pasternak JA, Ng S, Kaser T, Meurens F, Wilson HL (2014) Grouping Pig-Specific Responses to Mitogen with Similar Responder Animals may Facilitate the Interpretation of Results Obtained in an Out-Bred Animal Model . J Vaccines Vaccin 5: 242. doi: $10.4172 / 2157-7560.1000242$

Page 7 of 9

Myeloid cells and CD4+ $\mathrm{T}$ cell in the PBMCs than in the LPBMC population $(\mathrm{p}<0.05)$.

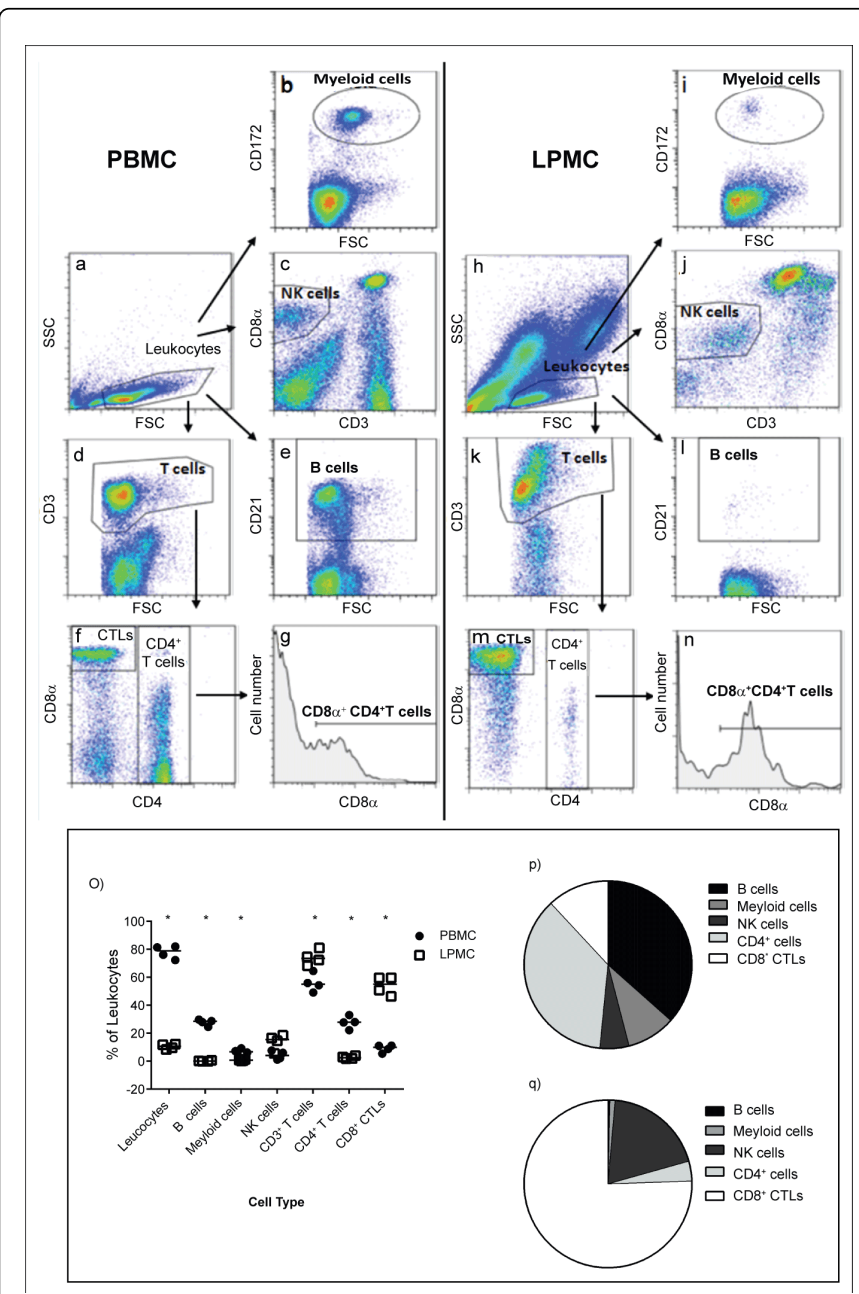

Figure 4: Frequency of leukocyte subsets in PBMC and LPMC using FCM analysis $A$ ) shows a representative FCM analysis $(n=4)$ from PBMCs (left) and LPMC (right) isolated from 6 week old pigs were analysed on the frequencies of different immune cell subsets using three-color FCM. Forward scatter (FSC) and side scatter (SSC) were used to gate on leukocytes (PBMCs (a) and LPMC (h) for further analysis of myeloid cells (CD172+; b and i), NK cells (CD3$\mathrm{CD} 8 \mathrm{a}+; \mathrm{c}$ and $\mathrm{j}), \mathrm{B}$ cells (CD21+; e and $\mathrm{l}$ ) and T cells (CD3+; d and $\mathrm{k})$. Gated $\mathrm{T}$ cells were then further analysed on their CD4/CD8a expression to determine the frequency of CTLs (CD4-CD8ahigh; $f$ and $\mathrm{m}$ ) and CD4+ T cells ( $\mathrm{f}$ and $\mathrm{m}$ ). CD8 $\alpha$ expression of CD4+ T cells was also investigated to define the frequency of experienced CD4+ T cells (CD8 $a+C D 4+; g$ and $n$ ). (o) Summarizes the results of this FCM analysis of all four analysed animals. Percentages from the PBMC population are represented by a closed circle and the percentages from the LPMC populations are represented by an open box. (p) and $(q)$ is a pie chart showing the relative average percentage of PBMCs and LPMCs from all 4 animals.

In turn, there was significantly higher CD3+ T cells and CTLS in the LPMCs than the PBMC population $(\mathrm{p}<0.05)$. We note that the data is extremely consistent across individual animals suggesting that any variation in functional responsiveness within a specific immune compartment in the assays above are most probably not caused by animal-specific differences in the cellular composition.

In figure $4 \mathrm{p}$ and $4 \mathrm{q}$, we see a pie chart representing the major cell populations in the PBMCs and LPMCs. The cell types that comprise the PBMCs are B cells $=\mathrm{CD} 4 \mathrm{~T}$ cells $>$ CTLs $>$ Myeloid cells $>$ NK cells. In contrast, the cell types that comprise the LPMCs are CTLs $>>>N K$ cells $>>\mathrm{CD} 4+\mathrm{T}$ cells $>$ Myeloid cells $>\mathrm{B}$ cells. Thus, it is reasonable to assume that there may indeed be two distinct subsets of cells in the PBMC population responsible for expressing the IL-10 and IFN $\gamma$ (Figure 3) and distinct subset of cells may express IL-12 in response to ConA or PMAi in the LPMCs (Figure 2b). Techniques such as cellsorting may be able to clarify which cell types are responsible.

\section{Conclusion}

This study demonstrates that tracking animal-specific responses to mitogen and grouping them with similar responder animals facilitates the interpretation of results obtained in an out-bred animal model. LPMCs from the pigs were primarily CTLs which did not show IL-10, IL-12, IFNa or IFN $\gamma$ production in response to Con A, but, they did produce IFN $\gamma$ in response to PMAi stimulation. PBMCs were a mixture of myeloid cells and $\mathrm{B}$ and $\mathrm{T}$ lymphocytes which produced IL-10, IFNa and IFN $\gamma$ in response to Con A. Animal-specific responses to Con A and PMAi were evident and may be due to differences in each animal's capacity to produce cytokine. If such differences in responses to ex vivo stimulation with mitogen are evident from pig cells, one begins to understand how challenging it may be to design an effective vaccine or treatment in out-bred animal species. Unlike in mice and other rodent models, humans and most livestock populations are out-bred populations; therefore it is clear that there is a tremendous advantage in studying treatments or vaccine responses across a group or herd where the response is likely going to be heterogeneous. It may be that multiple treatments or vaccination strategies should be undertaken to protect a greater percentage of the members of out-bred populations.

HLW conceived of and designed the experiments and wrote the manuscript. SN and JAP performed the laboratory experiments. TK and FM offered considerable advice on flow-cytometry technique and the subsequent data analysis. All authors contributed to the editing of the manuscript.

\section{Acknowledgments}

We gratefully acknowledge financial support from the Alberta Livestock and Meat Agency, Ontario Pork and the Saskatchewan Agriculture Development Fund (Saskatchewan Ministry of Agriculture and the Canada-Saskatchewan Growing Forward bi-lateral agreement). We would like to thank the members of PSCI for their excellent animal expertise as well as Donna Dent, Dr. Andrea Ladinig and Dr. John Harding for their excellent technical assistance with the BioPlex assays. HLW is an adjunct professor in the Department of Biochemistry and the School of Public Health at the University of Saskatchewan.

This manuscript is published with the permission of the Director of VIDO as journal series no. 704 . 
Citation: Pasternak JA, Ng S, Kaser T, Meurens F, Wilson HL (2014) Grouping Pig-Specific Responses to Mitogen with Similar Responder Animals may Facilitate the Interpretation of Results Obtained in an Out-Bred Animal Model . J Vaccines Vaccin 5: 242. doi: $10.4172 / 2157-7560.1000242$

Page 8 of 9

\section{References}

1. Neumann EJ, Kliebenstein JB, Johnson CD, Mabry JW, Bush EJ, et al. (2005) Assessment of the economic impact of porcine reproductive and respiratory syndrome on swine production in the United States. J Am Vet Med Assoc 227: 385-392.

2. Elahi S, Buchanan RM, Babiuk LA, Gerdts V (2006) Maternal immunity provides protection against pertussis in newborn piglets. Infect Immun 74: 2619-2627.

3. Dar A, Nichani A, Lai K, Potter A, Gerdts V, et al. (2010) All three classes of CpG ODNs up-regulate IP-10 gene in pigs. Res Vet Sci 88: 242-250.

4. Dar A, Lai K, Dent D, Potter A, Gerdts V, et al. (2012) Administration of poly[di(sodium carboxylatoethylphenoxy)]phosphazene (PCEP) as adjuvant activated mixed Th1/Th2 immune responses in pigs. Vet Immunol Immunopathol 146: 289-295.

5. Chai W, Burwinkel M, Wang Z, Palissa C, Esch B, et al. (2013) Antiviral effects of a probiotic Enterococcus faecium strain against transmissible gastroenteritis coronavirus. Arch Virol 158: 799-807.

6. Kunisawa J, Nochi T, Kiyono H (2008) Immunological commonalities and distinctions between airway and digestive immunity. Trends Immunol 29: 505-513.

7. Brandtzaeg P, Johansen FE (2005) Mucosal B cells: Phenotypic characteristics, transcriptional regulation, and homing properties. Immunological Reviews 206: 32-63.

8. Holmgren J, Czerkinsky C (2005) Mucosal immunity and vaccines. Nat Med 11: S45-53.

9. Brandtzaeg P, Farstad IN, Haraldsen G (1999) Regional specialization in the mucosal immune system: primed cells do not always home along the same track. Immunol Today 20: 267-277.

10. Kunkel EJ, Butcher EC (2003) Plasma-cell homing. Nat Rev Immunol 3: 822-829.

11. Campbell DJ, Debes GF, Johnston B, Wilson E, Butcher EC (2003) Targeting $\mathrm{T}$ cell responses by selective chemokine receptor expression. Semin Immunol 15: 277-286.

12. Dorn AD, Waters WR, Byers VM, Pesch BA, Wannemuehler MJ (2002) Characterization of mitogen-stimulated porcine lymphocytes using a stable fluorescent dye (PKH2) and multicolor flow cytometry. Vet Immunol Immunopathol 87: 1-10.

13. Olsen I, Sollid LM (2013) Pitfalls in determining the cytokine profile of human T cells. J Immunol Methods 390: 106-112.

14. Truneh A, Albert F, Golstein P, Schmitt-Verhulst AM (1985) Early steps of lymphocyte activation bypassed by synergy between calcium ionophores and phorbol ester. Nature 313: 318-320.

15. Sodhi A, Tarang S, Kesherwani V (2007) Concanavalin A induced expression of Toll-like receptors in murine peritoneal macrophages in vitro. Int Immunopharmacol 7: 454-463.

16. Kumar SP, Johnson DW, Okino FC, Muscoplat CC (1980) Monocyteinduced potentiation of bovine fetal thymocyte mitogenic responses to concanavalin A. Vet Immunol Immunopathol 1: 145-152.

17. Takashiba S, Van Dyke TE, Amar S, Murayama Y, Soskolne AW, et al. (1999) Differentiation of monocytes to macrophages primes cells for lipopolysaccharide stimulation via accumulation of cytoplasmic nuclear factor kappaB. Infect Immun 67: 5573-5578.

18. de Saint-Vis B, Fugier-Vivier I, Massacrier C, Gaillard C, Vanbervliet B, et al. (1998) The cytokine profile expressed by human dendritic cells is dependent on cell subtype and mode of activation. J Immunol 160: 1666-1676.

19. Crisci E, Ballester M, Domínguez J, Segalés J, Montoya M (2010) Increased numbers of myeloid and lymphoid IL-10 producing cells in spleen of pigs with naturally occurring postweaning multisystemic wasting syndrome. Vet Immunol Immunopathol 136: 305-310.

20. Kekarainen T, Montoya M, Mateu E, Segalés J (2008) Porcine circovirus type 2-induced interleukin-10 modulates recall antigen responses. J Gen Virol 89: 760-765
21. Taniguchi T, Ogasawara K, Takaoka A, Tanaka N (2001) IRF family of transcription factors as regulators of host defense. Annu Rev Immunol 19: 623-655.

22. Facchetti F, Vermi W, Mason D, Colonna M (2003) The plasmacytoid monocyte/interferon producing cells. Virchows Arch 443: 703-717.

23. Agnello D, Lankford CS, Bream J, Morinobu A, Gadina M, et al. (2003) Cytokines and transcription factors that regulate $\mathrm{T}$ helper cell differentiation: new players and new insights. J Clin Immunol 23: 147-161.

24. Jego G, Palucka AK, Blanck JP, Chalouni C, Pascual V, et al. (2003) Plasmacytoid dendritic cells induce plasma cell differentiation through type I interferon and interleukin 6. Immunity 19: 225-234.

25. Santini SM, Lapenta C, Logozzi M, Parlato S, Spada M, et al. (2000) Type I interferon as a powerful adjuvant for monocyte-derived dendritic cell development and activity in vitro and in Hu-PBL-SCID mice. J Exp Med 191: 1777-1788.

26. Trinchieri G (1995) Interleukin-12: a proinflammatory cytokine with immunoregulatory functions that bridge innate resistance and antigenspecific adaptive immunity. Annu Rev Immunol 13: 251-276.

27. Temblay JN, Bertelli E, Arques JL, Regoli M, Nicoletti C (2007) Production of IL-12 by Peyer patch-dendritic cells is critical for the resistance to food allergy. J Allergy Clin Immunol 120: 659-665.

28. Trinchieri G (2003) Interleukin-12 and the regulation of innate resistance and adaptive immunity. Nat Rev Immunol 3: 133-146.

29. Theiner G, Rössner S, Dalpke A, Bode K, Berger T, et al. (2008) TLR9 cooperates with TLR4 to increase IL-12 release by murine dendritic cells. Mol Immunol 45: 244-252.

30. Németh ZH, Mabley JG, Deitch EA, Szabó C, Haskó G (2001) Inhibition of the $\mathrm{Na}(+) / \mathrm{H}(+)$ antiporter suppresses IL-12 p40 production by mouse macrophages. Biochim Biophys Acta 1539: 233-242.

31. Macatonia SE, Hosken NA, Litton M, Vieira P, Hsieh CS, et al. (1995) Dendritic cells produce IL-12 and direct the development of Th1 cells from naive CD4+ T cells. J Immunol 154: 5071-5079.

32. Billiau A (1996) Interferon-gamma: biology and role in pathogenesis. Adv Immunol 62: 61-130.

33. Farrar MA, Schreiber RD (1993) The molecular cell biology of interferon-gamma and its receptor. Annu Rev Immunol 11: 571-611.

34. Trinchieri G, Perussia B (1985) Immune Interferon - a Pleiotropic Lymphokine with Multiple Effects. Immunol Today 6: 131-136.

35. Murakami D, Yamada H, Yajima T, Masuda A, Komune S, et al. (2007) Lipopolysaccharide inhalation exacerbates allergic airway inflammation by activating mast cells and promoting Th2 responses. Clin Exp Allergy 37: 339-347.

36. Ryzhov S, Goldstein AE, Matafonov A, Zeng D, Biaggioni I, et al. (2004) Adenosine-activated mast cells induce IgE synthesis by B lymphocytes: an A2B-mediated process involving Th2 cytokines IL-4 and IL-13 with implications for asthma. J Immunol 172: 7726-7733.

37. Fischer R, Tomé D, McGhee JR, Boyaka PN (2007) Th1 and Th2 cells are required for both eosinophil- and neutrophil-associated airway inflammatory responses in mice. Biochem Biophys Res Commun 357: 44-49.

38. Coffman RL, Mosmann TR (1991) CD4+ T-cell subsets: regulation of differentiation and function. Res Immunol 142: 7-9.

39. Mosmann TR, Coffman RL (1989) TH1 and TH2 cells: different patterns of lymphokine secretion lead to different functional properties. Annu Rev Immunol 7: 145-173.

40. Korn T, Bettelli E, Oukka M, Kuchroo VK (2009) IL-17 and Th17 Cells. Annu Rev Immunol 27: 485-517.

41. Kiros TG, van Kessel J, Babiuk LA, Gerdts V (2011) Induction, regulation and physiological role of IL-17 secreting helper T-cells isolated from PBMC, thymus, and lung lymphocytes of young pigs. Vet Immunol Immunopathol 144: 448-454.

42. Rašková G, Kováru F, Bártová J (2005) Cytokine production by porcine mononuclear leukocytes stimulated by mitogens. Acta Veterinaria Brno 74: $521-525$ 
Citation: Pasternak JA, Ng S, Kaser T, Meurens F, Wilson HL (2014) Grouping Pig-Specific Responses to Mitogen with Similar Responder Animals may Facilitate the Interpretation of Results Obtained in an Out-Bred Animal Model . J Vaccines Vaccin 5: 242. doi: $10.4172 / 2157-7560.1000242$

Page 9 of 9

43. Buchanan RM, Popowych Y, Arsic N, Townsend HG, Mutwiri GK, et al. (2011) B-cell activating factor (BAFF) promotes CpG ODN-induced B cell activation and proliferation. Cell Immunol 271: 16-28.

44. Pahlavani MA, Harris MD (1997) In vitro effects of melatonin on mitogen-induced lymphocyte proliferation and cytokine expression in young and old rats. Immunopharmacol Immunotoxicol 19: 327-337.

45. Kumar SP, Johnson DW, Okino FC, Muscoplat CC (1980) Monocyteinduced potentiation of bovine fetal thymocyte mitogenic responses to concanavalin A. Vet Immunol Immunopathol 1: 145-152.

46. Passwell JH, Goldring SR, Dayer JM (1982) Effects of concanavalin A and Fc fragments of IgG on human monocyte cAMP content: modulation of monocyte secretory function by cAMP. Immunology 46: 415-421.

47. Käser T, Gerner W, Hammer SE, Patzl M, Saalmüller A (2008) Phenotypic and functional characterisation of porcine CD4(+)CD25(high) regulatory T cells. Vet Immunol Immunopathol 122: 153-158.

48. Andersson M, Berg M, Fossum C, Jensen-Waern M (2007) Development of a microarray for studying porcine cytokine production in blood mononuclear cells and intestinal biopsies. J Vet Med A Physiol Pathol Clin Med 54: 161-168.

49. Chuang SL, Hayes PJ, Ogundipe E, Haddad M, MacDonald TT, et al (2009) Cow's milk protein-specific T-helper type I/II cytokine responses in infants with necrotizing enterocolitis. Pediatr Allergy Immunol 20: 45-52.

50. Donaldson L, Vuocolo T, Gray C, Strandberg Y, Reverter A, et al. (2005) Construction and validation of a Bovine Innate Immune Microarray. BMC Genomics 6: 135.

51. Wilkinson JM, Dyck MK, Dixon WT, Foxcroft GR, Dhakal S, et al. (2012) Transcriptomic analysis identifies candidate genes and functional networks controlling the response of porcine peripheral blood mononuclear cells to mitogenic stimulation. J Anim Sc 90: 3337-3352.

52. de Groot J, Kruijt L, Scholten JW, Boersma WJ, Buist WG, et al. (2005) Age, gender and litter-related variation in T-lymphocyte cytokine production in young pigs. Immunology 115: 495-505.
53. Trinchieri G, Gerosa F (1996) Immunoregulation by interleukin-12. J Leukoc Biol 59: 505-511.

54. Biron CA, Nguyen KB, Pien GC, Cousens LP, Salazar-Mather TP (1999) Natural killer cells in antiviral defense: function and regulation by innate cytokines. Annu Rev Immunol 17: 189-220.

55. Cella M, Fuchs A, Vermi W, Facchetti F, Otero K, et al. (2009) A human natural killer cell subset provides an innate source of IL-22 for mucosal immunity. Nature 457: 722-725.

56. James SP, Kwan WC, Sneller MC (1990) T cells in inductive and effector compartments of the intestinal mucosal immune system of nonhuman primates differ in lymphokine mRNA expression, lymphokine utilization, and regulatory function. J Immunol 144: 1251-1256.

57. Touraine JL, Hadden JW, Touraine F, Hadden EM, Estensen R, et al. (1977) Phorbol myristate acetate: a mitogen selective for a T-lymphocyte subpopulation. J Exp Med 145: 460-465.

58. Berry N, Ase K, Kikkawa U, Kishimoto A, Nishizuka Y (1989) Human T cell activation by phorbol esters and diacylglycerol analogues. J Immunol 143: 1407-1413.

59. Ria F, Penna G, Adorini L (1998) Th1 cells induce and Th2 inhibit antigen-dependent IL-12 secretion by dendritic cells. Eur J Immunol 28: 2003-2016.

60. Verthelyi D, Klinman DM (2003) Immunoregulatory activity of CpG oligonucleotides in humans and nonhuman primates. Clin Immunol 109: 64-71.

61. Leifer CA, Verthelyi D, Klinman DM (2003) Heterogeneity in the human response to immunostimulatory $\mathrm{CpG}$ oligodeoxynucleotides. J Immunother 26: 313-319.

62. Mena A, Nichani AK, Popowych Y, Ioannou XP, Godson DL, et al. (2003) Bovine and ovine blood mononuclear leukocytes differ markedly in innate immune responses induced by Class A and Class B CpGoligodeoxynucleotide. Oligonucleotides 13: 245-259.

63. Hedfors E, Holm G, Pettersson D (1975) Activation of human peripheral blood lymphocytes by concanavalin A dependence of monocytes. Clin Exp Immunol 22: 223-229. 